Research Article

\title{
Study on the Ground Movement in an Open-Pit Mine in the Case of Combined Surface and Underground Mining
}

\author{
Zhenwei Wang, Gaofeng Song $(\mathbb{D}$, and Kuo Ding $(\mathbb{D}$ \\ School of Civil Engineering, North China University of Technology, Beijing 100144, China \\ Correspondence should be addressed to Gaofeng Song; song.gaofeng@ncut.edu.cn
}

Received 14 December 2019; Revised 23 April 2020; Accepted 14 May 2020; Published 9 June 2020

Academic Editor: Stefano Bellucci

Copyright (c) 2020 Zhenwei Wang et al. This is an open access article distributed under the Creative Commons Attribution License, which permits unrestricted use, distribution, and reproduction in any medium, provided the original work is properly cited.

\begin{abstract}
The combined surface and underground mining method is typically used in an open-pit mine for better production and profits. However, the improved scale of mining operations at the combined mining conditions results in even more intensive strata movement and massive ground damages. This paper assesses the progressive development of the characteristics of roof movement with the longwall face advance and its influence on the ground movement at the slope area using physical models. The identification of strata zones at the combined mining conditions is also included. The results show the following: (1) the failure of the competent strong roof creates an inverse arch-shaped rock block structure, which compacts the loose rock fragments in the caved zone; (2) a bed separation occurs above the inverse structure at the top of the disturbed strata configuration and extends upward with the face advance until it approaches the continuous bending zone; (3) more intensive strata movement and ground damages are produced by the large-scale multiseam mining operations, while regular and more distinct strata zones in the disturbed configuration are identified for less intensive single-seam mining; and (4) the intensive and massive underground mining activities increase the slope strata movement at the surface mining side. This research suggests that a less intensive mining activity is preferred in the combined surface and underground mining conditions from the point of view of ground control.
\end{abstract}

\section{Introduction}

The surface mining method is mainly used for recovering the reserves at a shallow depth for economic reasons, while the underground mining method is adopted for deep seams. The combined surface and underground mining method is referred to as extracting the reserves using the underground mining method at an open-pit mine [1]. The surface and underground mining operations can be performed either at the same time or separately (simultaneous and nonsimultaneous combined mining operations). The study on the combined surface and underground mining in the case of iron mine has been extensively performed by Bakhtavar. $\mathrm{He}$ defined the two major problems in the field of combined mining, which is to find a practicable underground mining method for an open-pit mine for both simultaneous and nonsimultaneous combined mining and to optimize the schedule for the transition from surface mining to underground block cave, particularly in the case of nonsimultaneous mode [2]. For the nonsimultaneous combined mining case, the optimal time for the transition from the surface mining to underground mining was determined from a stochastic mathematical model, and the favourable depth for the transition in an iron mine was determined by considering both geological and economic models $[3,4]$. The geotechnical challenges were identified as the induced stress, subsidence, and instability of mine structures which can be mitigated or eliminated by optimization of the crown pillar dimensions [5]. The optimum size of the pillar was calculated from a dimensional analysis to balance the geotechnical problems and economic benefits [6]. In the field of coal mining, the combined mining system can be classified into two categories according to the seam inclination [7]. For steeply inclined seams, the surface mining is operated at the 
shallow part, while the underground faces (typically the longwall top coal caving method) are used to extract the coal at a deeper depth. On the other hand, the near-flat seams are worked by both the surface and underground mining operations at approximately the same level. The combined method has been practiced for decades in a number of coal mines in China with further improved production and economic profits. However, one would intuitively expect a more intensive mining-induced ground movement and therefore more damages to the overlying strata and the ground structures especially when the underground longwall faces approach the slopes of the open pit or the dump. This is not only because the mining scale and intensity are significantly increased, but also because it is less likely for the shallow overburden strata in an open-pit mine to form a selfsupporting structure. As a result, the combined mining method differs from the other mining technologies in the excavated strata configuration (i.e., the open-pit slope) and the improved ground movement caused by the extensive scale of the surface and underground mining activities. Figure 1 shows the ground movement of the surface and the slope steps captured at Anjialing mine, Shanxi Province. The ground is influenced multiple times by the surface and underground mining activities, with the massive crack observed on the ground and the shear movement at the slope strata.

Numerical and physical modelling of the roof caving behaviours has been frequently documented in previous studies for understanding the progressive development of mining-induced fractures and mechanism of strata movement around underground openings. The models have considered the face advance rate on ground movement [8], the extension of caved and fractured zone heights [9], longwall face failure and shield-strata interactions [10-12], and the impact loadings on shields [13]. These models have not considered the combined surface and underground mining method. Sun believes that the damages to the ground are enhanced due to the overlap of the ground movement areas caused by the surface and underground mining activities [14]. Zhu et al. optimized the dimensions of the solid coal pillar (located from one end of the underground longwall face to the slope edge) to improve the stability of the slope $[15,16]$. Liu et al. analyzed the influence of the critical distance (the distance from the face position at the slope side perpendicular to the upper slope) on the failure of the slope, based on which they suggested the proper underground mining sequences [17]. However, these models mainly considered the stability and movement of the pit slope; the distribution of the three zones in the overburden for a combined surface and underground is not included.

The three-zone theories of the strata movement in the vertical and horizontal directions are widely accepted by most researchers $[18,19]$. The disturbed overlying strata caused by the longwall mining can be identified as three zones in the vertical direction, i.e., the caved zone (Zone I), the fractured zone (Zone II), and the continuous bending zone (Zone III) as shown in Figure 2 [18]. The fractured zone is further divided into the fragmented rock blocks zone, the vertical fracture propagating-through zone, and the horizontally separated zone $[18,19]$. The three zones may be reduced to two zones with an absence of the continuous deformation zone at the top in the shallow coal mines in Inner Mongolia of China where the top cover is mainly the unsolidified loose formation [20,21]. The fractured zone therefore extends to the ground surface as the face advances, leading to an extensive ground movement. The height of the three zones (especially the fractured zone) is closely related to the connectivity of the waste gas and water [22] and can be determined from the empirical equations [23-25], numerical and physical models [26-28], vertical borehole observations $[29,30]$, and the microseismic monitoring method [31]. Meanwhile, the movement of the overlying strata can also be divided into three zones in the horizontal direction according to the surface subsidence curve. The three horizontal zones are identified as the solid coal support zone (Zone $\mathrm{A}$, where the curve shows the least deformation and the subsidence rate), the separation zone (Zone B, where the bed separation mostly occurs), and the recompacted zone (Zone $\mathrm{C}$, where the loose gob materials in the caved zone and the horizontal bed separation in the fractured zone are recompacted and the surface settlement reaches the maximum).

This paper attempts to study the influence of underground mining on both the overburden migration and the slope stability from physical models. The model configurations are selected from different geological sections of an open-pit mine. The 3 models in the work include different face dimensions: the adjacent-seam mining and multipleseam mining. The paper has three goals: (1) obtain the progressive development of roof failure and mining-induced strata movement for the combined surface and underground mining conditions; (2) identify the vertical and horizontal zones of the disturbed overburden; and (3) assess the slope behaviours influenced by the underground mining activity.

\section{Model Development}

2.1. Mine Description. The representative physical model in this study is based on the geological and mining conditions at the Anjialing open-pit mine, Pingshuo, Shanxi Province, where the combined surface and underground mining method is adopted for recovering the 4th and 9th seams at the mine site. The total thickness of No. 4 seam is $8.6-16.8 \mathrm{~m}$ and averages at $13.64 \mathrm{~m}$. The immediate roof above No. 4 seam is sandstone with an average thickness of $7.33 \mathrm{~m}$. The weak mudstone and sandy mudstone occasionally occur above the coal seam but cave in upon the face advance. The immediate roof below No. 4 seam is mainly mudstone, below which is the $6.9-16.7 \mathrm{~m}$ thick No. 9 seam averaging at $13.8 \mathrm{~m}$. The rock strata between the two near-flat seams are 17.0-57.2 m (average $31.1 \mathrm{~m}$ ). No. 4 and No. 9 seams were worked at a depth of 170-250 $\mathrm{m}$ using the surface mining method. Currently, the coal mine is also recovering the coal seams using the underground longwall top coal caving method. The width of the underground longwall face is $240 \mathrm{~m}$, while the length and the position of the longwall face relative to the slope should be determined based on its influence on the ground movement and the slope stability. 


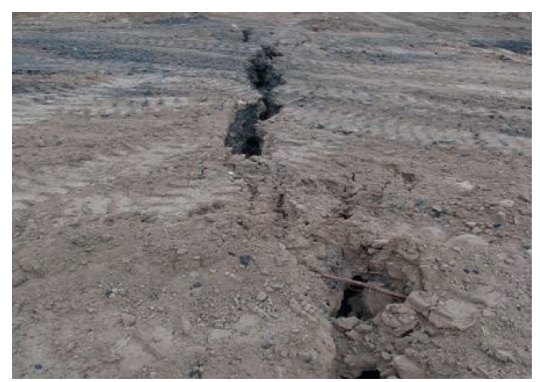

(a)

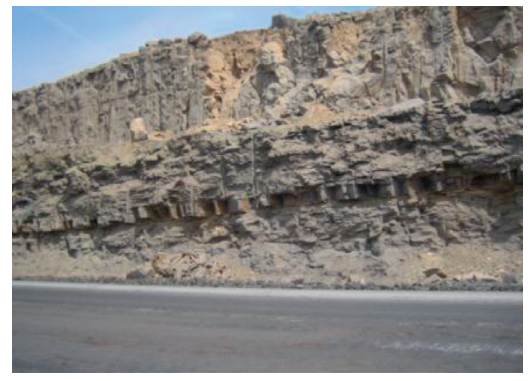

(b)

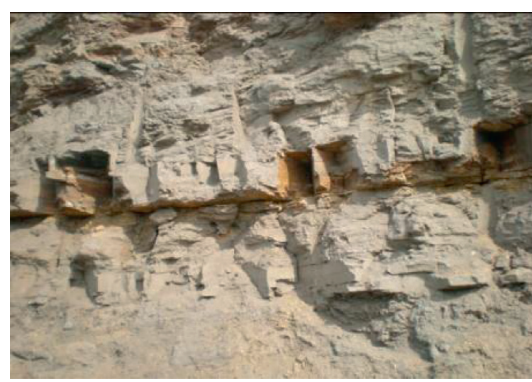

(c)

FIgURE 1: Ground movement caused by the surface and underground mining activities at the Anjialing open-pit mine, Shanxi Province. (a) Massive ground crack on step 1405. (b) Shear movement of rock strata on step 1300. (c) Shear movement on step 1270.

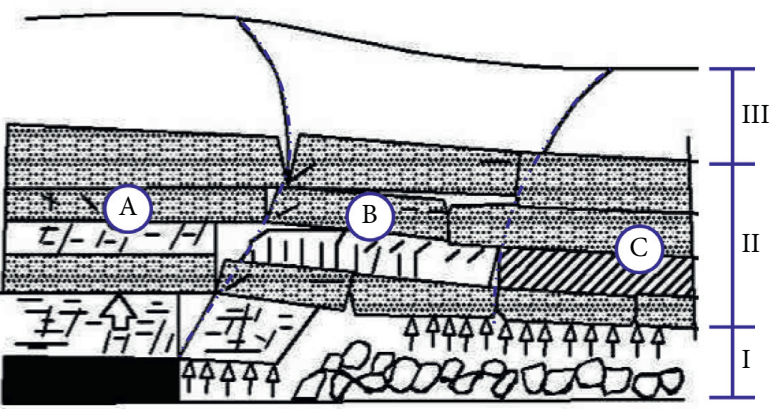

I: caved zone

II: fractured zone

A: solid coal support zone

III: continuous bending zone

C: recompacted zone

FIGURE 2: The three-zone distribution of the overlying strata movement in the vertical and horizontal directions caused by longwall mining.

2.2. Similarity Principles and Construction Materials. The physical modelling approach is utilized in this work to reproduce the progressive development of the ground movement and the slope stability of an open-pit mine using the combined surface and underground mining method. One of the most important aspects of the physical modelling is that the physical model must follow a number of similarity principles, according to which the physical features of the model and the prototype case (full-scale case) should be similar in terms of geometry, time, density, and strength. The measurements in the physical model can, therefore, be compared with the real case. The above coefficients are defined as the ratios of corresponding real case parameters over the small-scale physical model and must be kept as constants, which are determined based on the mechanical properties of the modelling materials and the size of the physical modelling rig $[8,12]$. In this work, the geometry, time, density, and strength similarity coefficients are determined as 250,10,1.47, and 147, respectively.

Proper geomechanical modelling materials are carefully selected to construct the physical model for realistically representing the strata movement. In this work, the construction materials are a mixture of sand, gypsum, and lime with a proper proportion of water. The solid materials are

fully mixed before the addition of water to ensure the general homogeneity. The proportions of the physical materials are carefully determined through a trial-and-error process, so that the strata could behave and cave in in a similar way to the real case. The proportions and mechanical properties of the physical materials are given in Tables 1 and 2, respectively.

2.3. Physical Modelling Rig and Model Preparation. The 2D strain plain physical modelling rig used in this research is $500 \mathrm{~cm}$ in length, $40 \mathrm{~cm}$ in width, and $150 \mathrm{~cm}$ in height (see Figure 3). The frame is larger than the traditional ones in order to incorporate the large-scale surface and underground mining activities. Physical materials are first placed in the modelling steel frame and are then compacted to the designed height. The physical model is constructed layer by layer to ensure the overall strength and height of the model. No. 4 and No. 9 seams and the strata shown in Figure 4(a) at the Anjialing open-pit mine are modelled in this study. The right side of the physical model is a slope created by the previous surface mining, while the underground longwall faces are currently operated in the physical models starting from the left side. The physical model has roller boundaries along the left and right side and at the bottom. Figure 3 shows the overall geometry of the physical model. Note that the geometric similarity is $250: 1$ in this work; therefore, the $500 \mathrm{~cm}$ long physical model simulates a total of $1250 \mathrm{~m}$ in the real case.

Three models are developed in this research (Models I, II, and III) for representing three geological sections in the studied mine site. In Model I, Face $A_{1}$ and Face $A_{2}$ are advanced a total of $200 \mathrm{~m}$ in the upper No. 4 seam, followed by a $500 \mathrm{~m}$ development of Face $B_{1}$ in the lower No. 9 seam. A $50 \mathrm{~m}$ wide solid coal pillar is maintained between Faces $A_{1}$ and $A_{2}$. In Model II, Face $B_{2}$ and Face $B_{3}$ are located in the lower No. 9 seam and are worked a total distance of $170 \mathrm{~m}$ and $370 \mathrm{~m}$, respectively. A $50 \mathrm{~m}$ wide solid coal pillar is left between the two faces. In Model III, Face $\mathrm{B}_{4}$ is mined a total of $500 \mathrm{~m}$ in No. 9 seam. The models are developed to study the progressive development of the ground movement, the vertical displacement of the roof strata, and the displacement field of the slope. A 3D digital close-range industrial photogrammetry system is used in this research for providing a 
TABLe 1: Proportions of the physical materials in terms of weight to construct different lithologies in the physical model.

\begin{tabular}{lcccc}
\hline Lithologies in the model & \multicolumn{2}{c}{$\begin{array}{c}\text { Percentage of the solid materials by weight } \\
\text { Sand (\%) }\end{array}$} & $\begin{array}{c}\text { Gypsum (\%) } \\
\text { Lime (\%) }\end{array}$ & $\begin{array}{c}\text { Percentage of the water over solid } \\
\text { materials by weight (\%) }\end{array}$ \\
\hline Artificial fill & 87.5 & 8.75 & 3.75 & 10 \\
Loose soil & 87.5 & 8.75 & 3.75 & 10 \\
Weathered sandstone & 80 & 10 & 10 & 10 \\
Sandstone & 75 & 12.5 & 12.5 & 10 \\
Clay & 85.7 & 4.3 & 10 & 10 \\
No. 4 coal seam & 83.3 & 8.35 & 8.35 & 10 \\
Sandy mudstone & 85.7 & 6.3 & 10 & 10 \\
Fine sandstone & 80 & 6 & 14 & 10 \\
Siltstone & 80 & 10 & 10 & 10 \\
Malmstone & 80 & 8.35 & 8.35 & 10 \\
No. 9 coal seam & 83.3 & 10 & 10 & 10 \\
Mudstone & 80 & 8.35 & 8.35 & 10 \\
No. 11 coal seam & 83.3 & 7.5 & 17.5 & 10 \\
Medium-fine sandstone & 75 & &
\end{tabular}

TABLE 2: Mechanical properties for different lithologies.

\begin{tabular}{|c|c|c|c|c|c|c|}
\hline Lithology & $\begin{array}{c}\text { Compression strength } \\
(\mathrm{MPa})\end{array}$ & $\begin{array}{c}\text { Internal friction } \\
\text { angle }\left({ }^{\circ}\right)\end{array}$ & $\begin{array}{c}\text { Cohesion } \\
(\mathrm{MPa})\end{array}$ & $\begin{array}{l}\text { Unit weight } \\
\left(\mathrm{kg} \cdot \mathrm{m}^{-3}\right)\end{array}$ & $\begin{array}{l}\text { Elastic modulus } \\
(\mathrm{MPa})\end{array}$ & $\begin{array}{l}\text { Poisson's } \\
\text { ratio }\end{array}$ \\
\hline Artificial fill & 1.8 & 16 & 0.112 & 1650 & 12 & 0.45 \\
\hline Loose soil & 1.8 & 18 & 0.125 & 1960 & 15 & 0.42 \\
\hline $\begin{array}{l}\text { Weathered } \\
\text { sandstone }\end{array}$ & 56.3 & 38 & 2.5 & 2300 & 2000 & 0.36 \\
\hline Sandstone & 95.1 & 39 & 3 & 2380 & 4200 & 0.33 \\
\hline Clay & 58.1 & 40 & 0.5 & 2355 & 2015 & 0.23 \\
\hline No. 4 coal seam & 40.7 & 36 & 1.62 & 1440 & 1000 & 0.38 \\
\hline Sandy mudstone & 63.8 & 39 & 0.5 & 2360 & 2050 & 0.24 \\
\hline Fine sandstone & 99.4 & 40 & 3.1 & 2380 & 4300 & 0.33 \\
\hline Siltstone & 107.4 & 38 & 5 & 2600 & 4800 & 0.32 \\
\hline Malmstone & 54.4 & 38 & 0.4 & 2350 & 2000 & 0.25 \\
\hline No. 9 coal seam & 38.4 & 39 & 1.62 & 1330 & 1200 & 0.36 \\
\hline Mudstone & 54.5 & 38 & 0.4 & 2300 & 2000 & 0.25 \\
\hline No. 11 coal seam & 36.6 & 36 & 1.62 & 1400 & 1300 & 0.35 \\
\hline $\begin{array}{l}\text { Medium-fine } \\
\text { sandstone }\end{array}$ & 99.8 & 40 & 3.1 & 2390 & 4300 & 0.33 \\
\hline
\end{tabular}

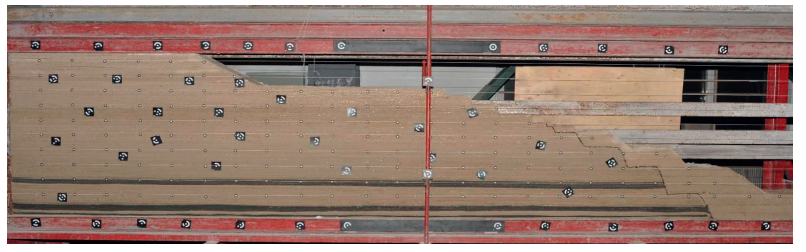

FIGURE 3: The physical modelling rig and the finished 2D model.

precise, rapid, automatic, and continuous measurement of the strata vertical displacement above the longwall workings. The ground movement in the slope area is also provided by recording the slope deformation field using the digital speckle correlation method. The camera measuring system yields more accurate strata movement results than the traditional electronic theodolite.

\section{Results and Analysis}

3.1. Model I. Figure 5 plots the progressive development of the ground movement in Model I for recovering both No. 4 and No. 9 seams. Face $A_{1}$ in the upper seam was first mined. The face starts at approximately $180 \mathrm{~m}$ away from the left boundary of the rig. The roof caves in regularly in the gob area with the face advance, and the caved zone height reaches $10 \mathrm{~m}$ above the seam after $120 \mathrm{~m}$ of the face advance (Figure 5(a)). With a further $50 \mathrm{~m}$ of face development, the more component sandstone roof bends and forms an inverse arch-shaped structure (see the dashed line in Figure 5(b)), beneath which the previously caved loose materials are compacted. A bed separation is also observed above the arch structure at the top of the disturbed overburden, which extends $42.5 \mathrm{~m}$ above the seam. Face $\mathrm{A}_{1}$ advances another $30 \mathrm{~m}$ and ceases after a total of $200 \mathrm{~m}$ development. During this period, the immediate roof caves in upon the face advance (Figure 5(c)). The main roof beam above the shield is fixed at one end at the solid coal face side and is supported by the inverse arch-shaped structure at the other. As a result, the convergence of the roof should be small and the loading condition of the longwall shield should be better off at this position. 


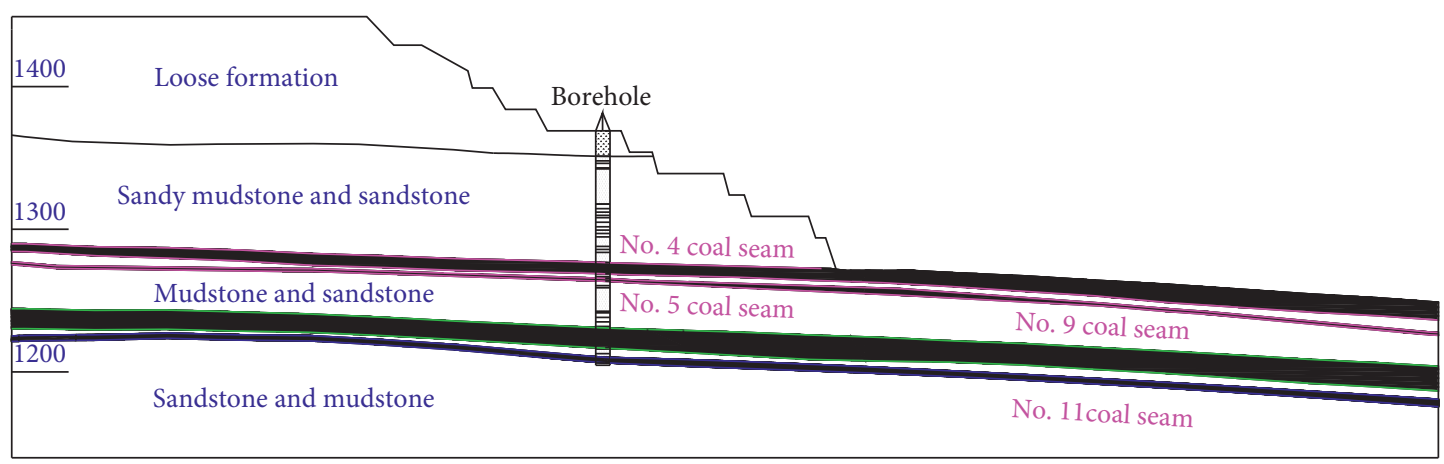

(a)

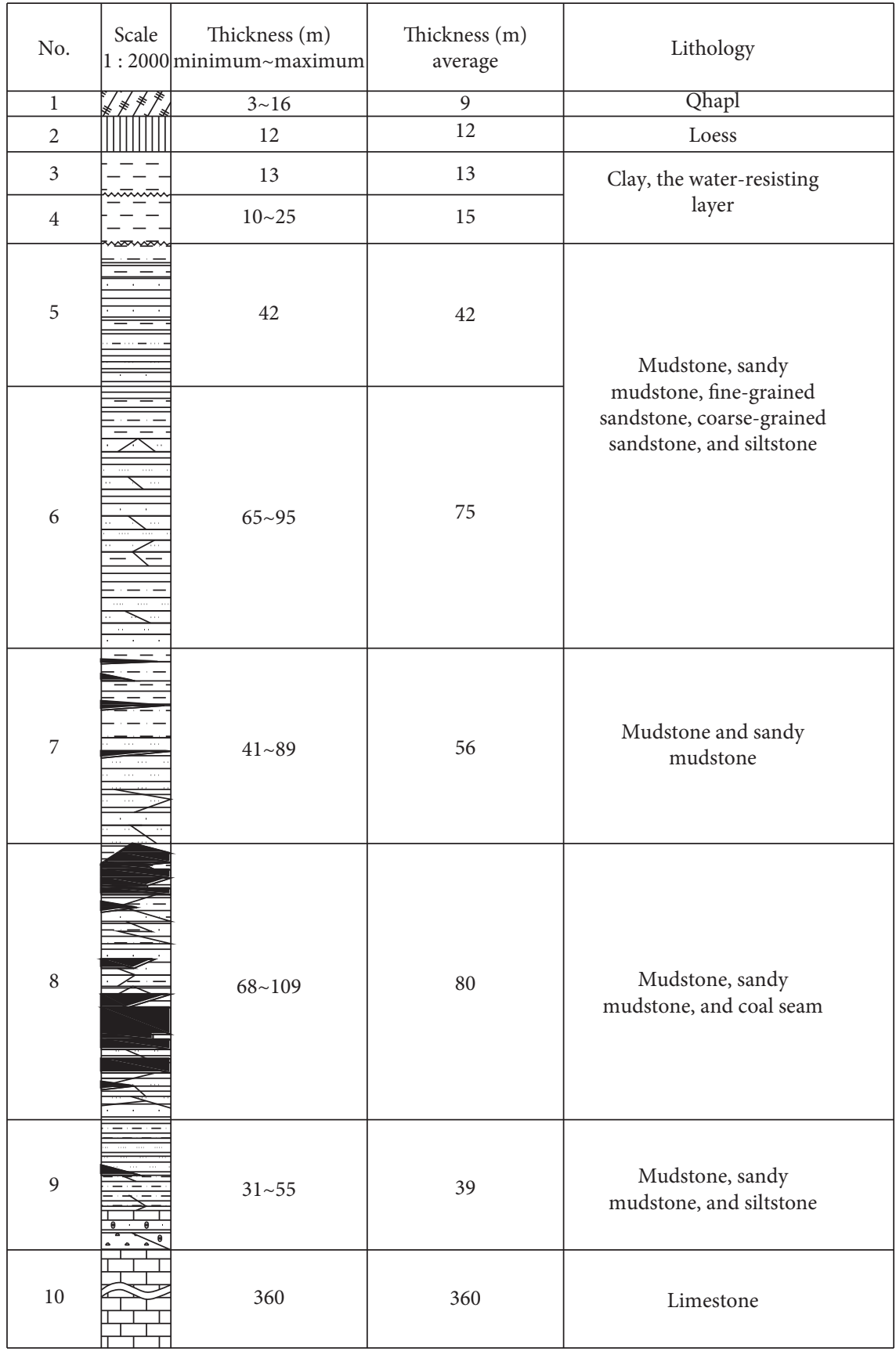

(b)

FIgURE 4: (a) Geological section profile. (b) General stratigraphy for the Anjialing mine. 


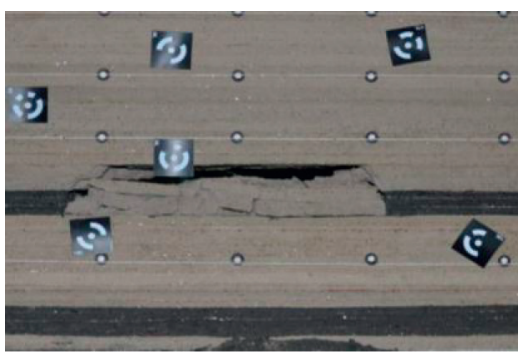

(a)

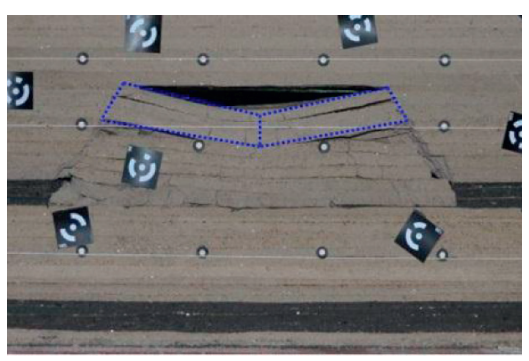

(b)

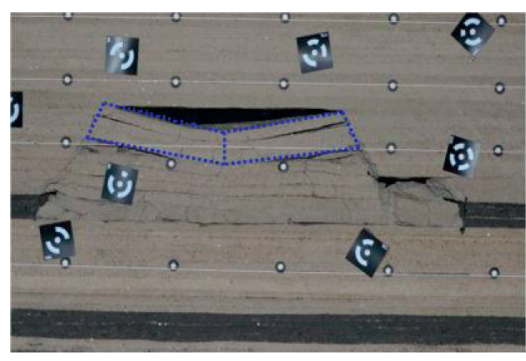

(c)

FIgURe 5: Progressive development of strata movement with advance of Face $\mathrm{A}_{1}$. Face advance distance: (a) $120 \mathrm{~m}$, (b) $170 \mathrm{~m}$, and (c) $200 \mathrm{~m}$.

After completion of Face $A_{1}$, a $50 \mathrm{~m}$ wide coal pillar was left between the previous Face $A_{1}$ and the adjacent active Face $A_{2}$. The strata movement for mining Face $A_{2}$ is shown in Figure 6, which is similar to that of the previous face. The extension of the broken strata increases with the face development. It also reaches $42.5 \mathrm{~m}$ after the completion of Face $\mathrm{A}_{2}$ at a total of $200 \mathrm{~m}$ face advance (Figure 6(c)). However, the overall dimension of the disturbed configuration for Face $\mathrm{A}_{2}$ is slightly larger than the previous one, and the gob materials are less compacted by the above inverse arch-shaped strata. The overburden strata above the coal pillar (outlined by the blue dot lines in Figure 6(c)) remain stable and intact. The angle of break (defined as the angle between the vertical line and the edge of stable strata above the pillar) is found at approximately $26^{\circ}$ for both panels. The solid coal pillar may yield due to the compression of the stable configuration and the abutment pressures. Mine hazards such as violent coal bursts and extraordinary distortion of the pillar or mine entries may occur.

The influence of multiple-seam mining operations is included in this work by mining Face $B_{1}$ in the lower seam after the completion of the two faces in the upper seam. In the beginning, the immediate roof collapses in the gob area with the face advance, but the main roof remains intact and the caved height has not reached the previously mined-out gob in the upper seam (Figures $7(\mathrm{a})$ and $7(\mathrm{~b})$ ). In other words, the disturbed strata for Face $B_{1}$ in the lower seam have not reached the upper gob area; the upper and lower gobs are separated. The loading conditions for the shield and longwall face should be better off at this position since the overburden pressure is partially released through the previous upper gob. After the face has developed $200 \mathrm{~m}$, the main roof caves in as the limit of overhang length is reached (Figure 7(c)). The roof channels between the two coal seams fail completely and the upper gob collapses. The caved zone for the active face extends upward and connects with the upper gob. This may increase the intensity of the roof weighting as well as the shield loading. The channels form an inverse arch-shaped structure compacting the below gob materials and a load-bearing structure supporting the overburden. A huge separation is created at the top of the gob above the structure. The angles of break for both upper and lower faces are similar.
Face $B_{1}$ advances to the above coal pillar position (Figure 7(d)). The above stable configuration (sitting on the coal pillar between the two upper faces, see Figure 6(c)) transfers the overburden pressures to the active longwall panel and shield. Hence, poor face stability and the tremendous difficulty in advancing the shields might be expected. The load environment in the open face area could return to the previous level only after the face passes the coal pillar area. The face then advances under the upper gob area of Face $\mathrm{A}_{2}$ (Figure $7(\mathrm{e})$ ). The lower gob connects the upper one upon the failure of the roof channel (Figure $7(f)$ ).

Face $B_{1}$ ceases after $500 \mathrm{~m}$ of face development. The final view of the ground movement and the three zones in the horizontal and vertical directions are shown in Figure 8. The zones are different with the typical zone identification shown in Figure 2 because of the extraction of multiple seams. The intensity and extension of ground movement is increased by the multiple-seam mining. A massive ground fracture is observed on the surface above the start position of the longwall face, as well as the shear movement of strata on the slope step. This is consistent with the field observation shown in Figure 1.

Figure 9 shows the vertical displacement of the strata along the face length at different layers above No. 9 seam. Generally, the displacement maximizes at the middle positions of Faces $A_{1}$ and $A_{2}$ and reaches a smaller plateau above the solid coal pillar between the two faces. The twopeak shaped curves are formed because of the existence of the stable configuration above the solid coal pillar. It is also noted that the strata at a deeper depth (closer to No. 9 seam) show a larger vertical displacement, with an exception that the roof at $15 \mathrm{~m}$ above the seam presents the least vertical displacement and stabilizes at this level (see the blue line). This differs from the other two-peak curves because the roof at $15 \mathrm{~m}$ above No. 9 seam stays in the roof channel between the two seams; therefore, the displacement simply represents the strata movement for mining Face $B_{1}$ rather than for extracting the multiple seams.

The vertical displacement at the slope area is recorded using the digital speckle correlation method. It may not produce the most refined details of the slope displacement field, but the general influence of the underground mining activity to the slope behaviour can be obtained. Figure 10 shows the displacement field after completion of Faces $A_{1}$, 


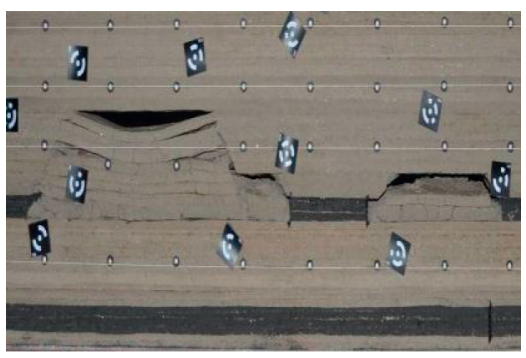

(a)

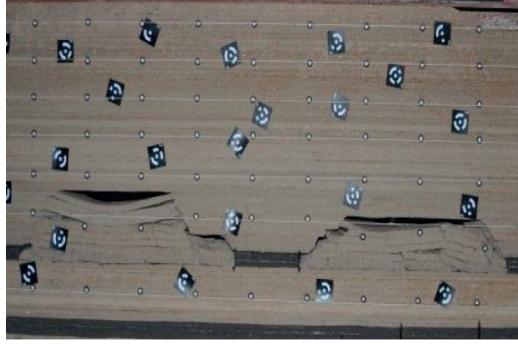

(b)

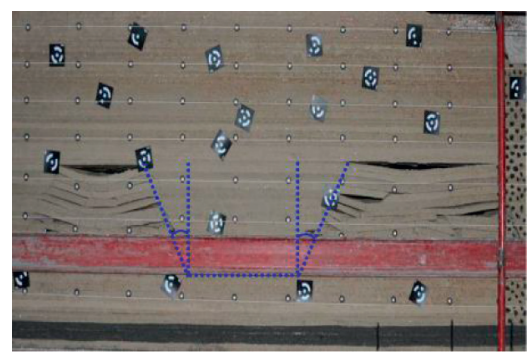

(c)

FIGURE 6: Progressive development of strata movement with advance of Face $\mathrm{A}_{2}$. Face advance distance: (a) $120 \mathrm{~m}$, (b) $170 \mathrm{~m}$, and (c) $200 \mathrm{~m}$.

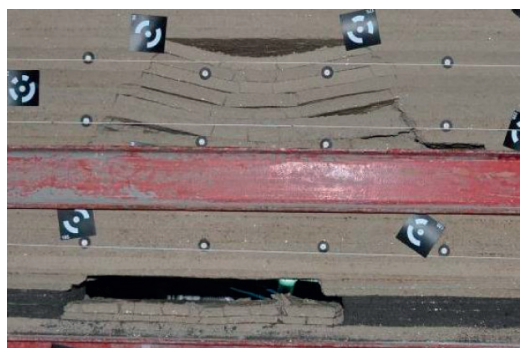

(a)

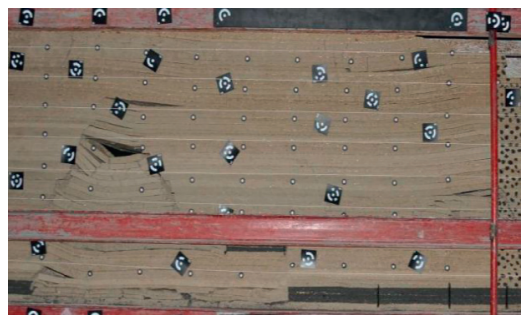

(d)

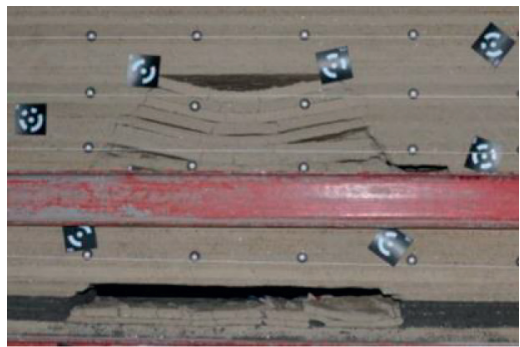

(b)

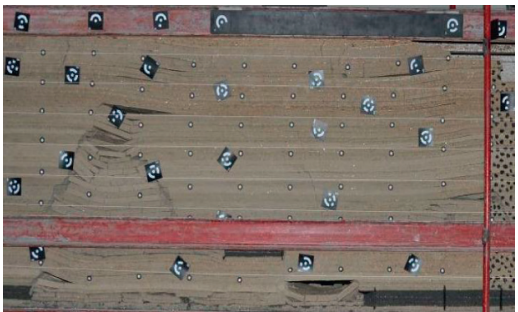

(e)

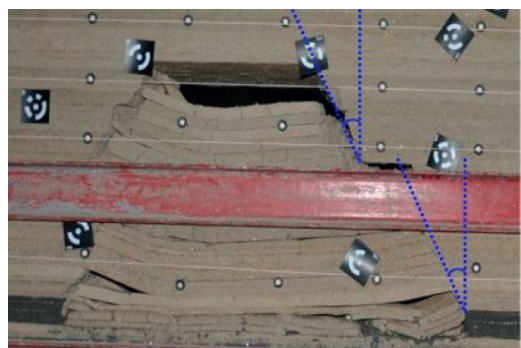

(c)

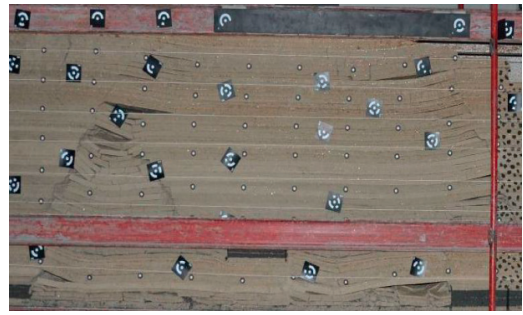

(f)

FIgURE 7: Progressive development of strata movement with advance of Face $B_{1}$. Face advance distance: (a) $120 \mathrm{~m}$, (b) $150 \mathrm{~m}$, (c) $200 \mathrm{~m}$, (d) $250 \mathrm{~m}$, (e) $325 \mathrm{~m}$, and (f) $400 \mathrm{~m}$.

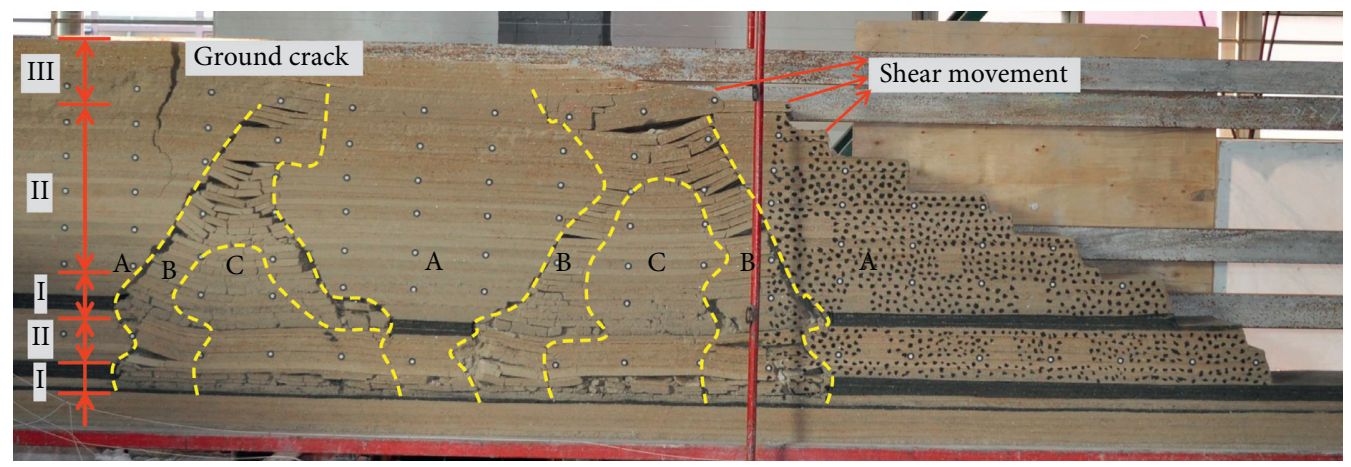

FIGURE 8: Final view of the ground movement at completion of Face $\mathrm{B}_{1}$. I: caved zone; II: fractured zone; and III: continuous bending zone. (A) stable zone; (B) separation zone; and (C) recompacted zone.

$A_{2}$, and $B_{1}$, respectively. The extraction of Face $A_{1}$ shows limited impact on the subsidence of the slope (Figure 10(a)), since the finish position of Face $A_{1}$ is located more than $250 \mathrm{~m}$ away from the slope area. The magnitude of the displacement increases with the completion of Faces $A_{2}$ and $B_{1}$ (Figures $10(b)$ and $10(c)$ ). Hence, it is inferred that the slope movement is gradually increased with the increase of the scale and intensity of mining activities.

3.2. Model II. In Model II, Faces $\mathrm{B}_{2}$ and $\mathrm{B}_{3}$ in the lower seam are mined with a $50 \mathrm{~m}$ coal pillar left between the two panels. The above No. 4 seam remains unmined. The strata 


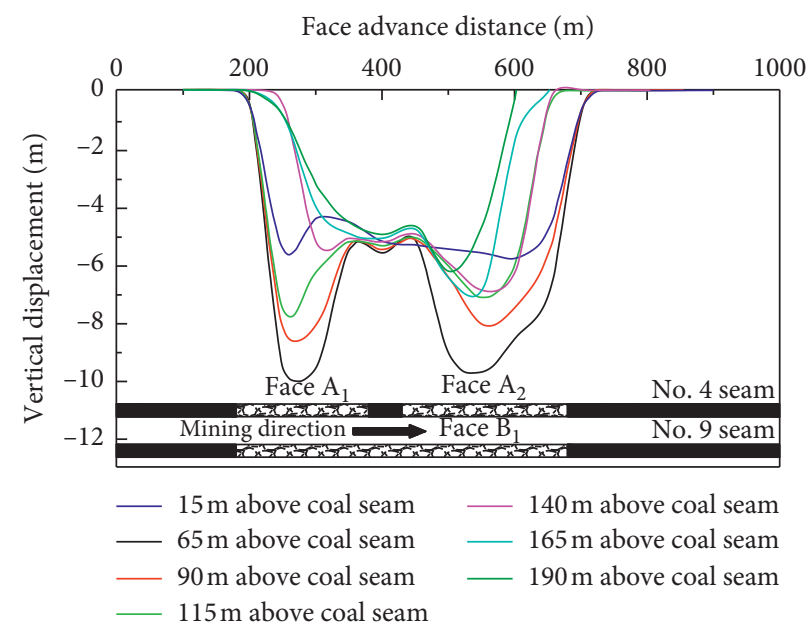

Figure 9: Strata vertical displacement after completion of Faces $A_{1}, A_{2}$, and $B_{1}$.

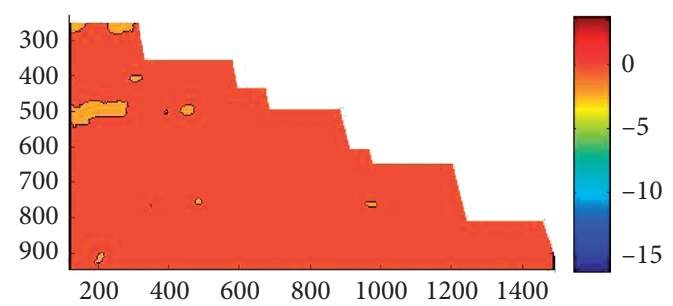

(a)

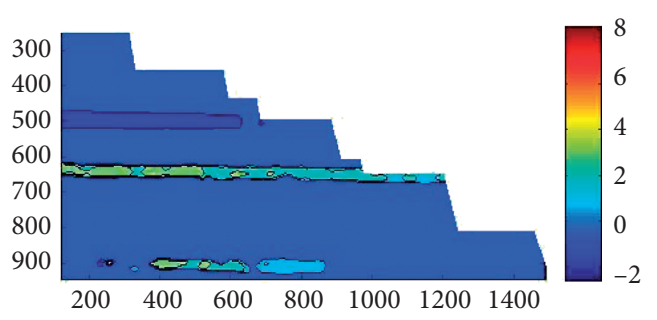

(b)

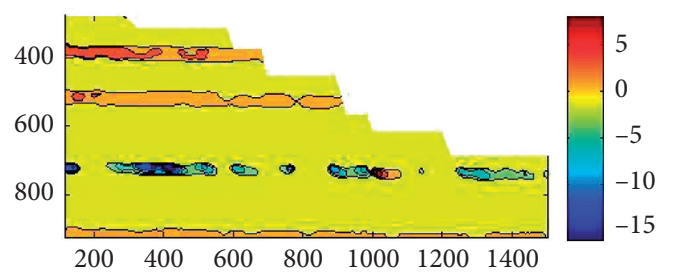

(c)

FIGURE 10: Slope vertical displacement contour after completion of Faces (a) $A_{1}$, (b) $A_{2}$, and (c) $B_{1}$.

movement with the advance of Face $\mathrm{B}_{2}$ is shown in Figure 11. The caved height extends upward with the face advance (Figures 11(a)-11(c)). The inverse arch-shaped structure compacts the caved loose materials in the gob area (Figure 11(d)). Face $B_{2}$ ceases after $170 \mathrm{~m}$ of face development.

The adjacent Face $\mathrm{B}_{3}$ is mined after the completion of the previous Face $B_{2}$. The immediate roof caves in upon the face advance. Loose gob materials are regularly placed in the gob area and form the caved zone (Figures 12(a) and 12(b)). With the further face development, the disturbed overburden develops to the fractured zone, and the gob wastes are compacted by the inverse arch-shaped structure (Figures 12(c)-12(e)). The huge bed separation at the top of the disturbed configuration is closed and recreated with the face advance at each face position (see Figures 12(a)-12(e)). However, the recreation of the bed separation terminates after $370 \mathrm{~m}$ of face advance when the disturbed strata configuration extends to the continuous bending zone (Figure 12(f)).

Figure 13 provides a final view of the strata movement after completion of Faces $\mathrm{B}_{2}$ and $\mathrm{B}_{3}$. The caved zone, fractured zone, and continuous zone in the vertical direction and the stable zone, separation zone, and the recompacted zone in the horizontal direction are also identified. Since Face $\mathrm{B}_{2}$ only develops a limited distance, no bending zone is observed. By comparison, the bending zone for Face $\mathrm{B}_{3}$ develops to the ground surface and causes the ground subsidence and surface cracks that are less significant than Model I.

The roof vertical displacement for Model II is given in Figure 14. The maximum displacement is approximately $6 \mathrm{~m}$ measuring at the strata at $15 \mathrm{~m}$ above No. 9 seam. It decreases with the increase of the distance above the seam and reduces to approximately $3.2 \mathrm{~m}$ for the strata at $165 \mathrm{~m}$ above the seam. The roof vertical displacement above Face $B_{2}$ 


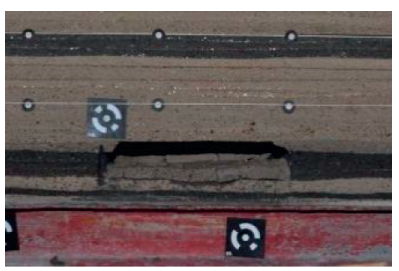

(a)

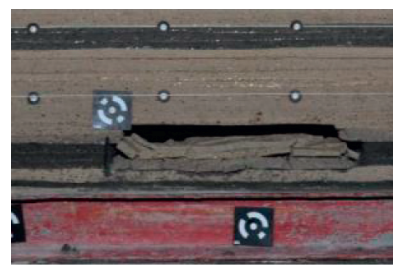

(b)

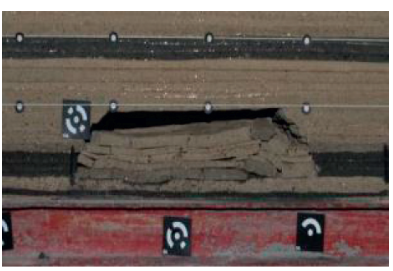

(c)

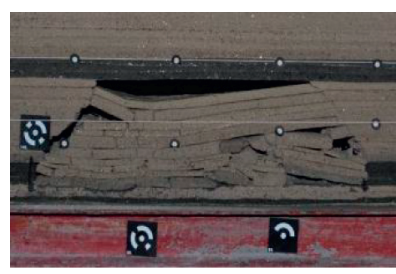

(d)

Figure 11: Progressive development of strata movement with advance of Face $B_{2}$. Face advance distance: (a) $70 \mathrm{~m}$, (b) $90 \mathrm{~m}$, (c) $120 \mathrm{~m}$, and (d) $170 \mathrm{~m}$.

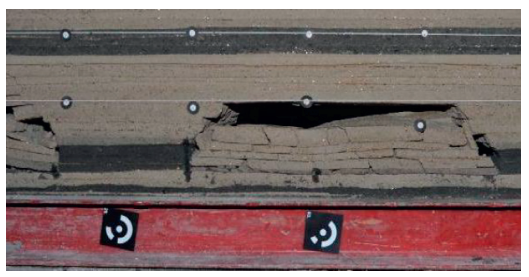

(a)

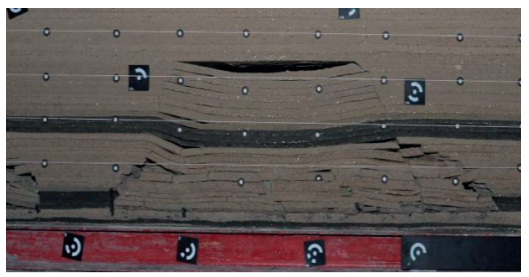

(d)

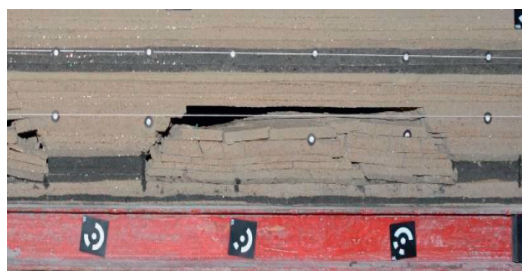

(b)

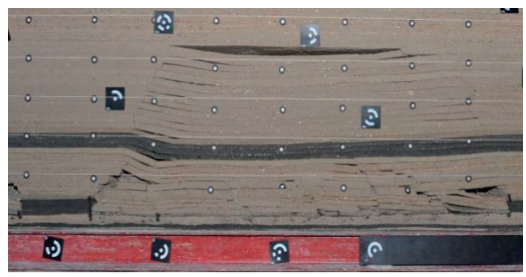

(e)

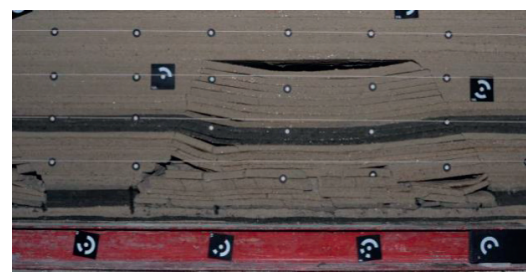

(c)

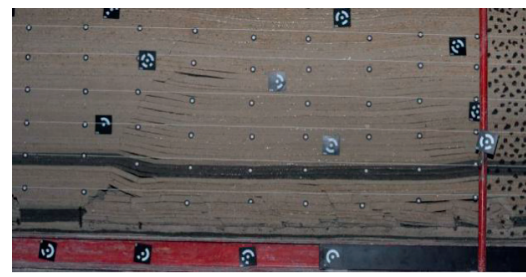

(f)

Figure 12: Progressive development of strata movement with advance of Face $B_{3}$. Face advance distance: (a) $120 \mathrm{~m}$, (b) $170 \mathrm{~m}$, (c) $230 \mathrm{~m}$, (d) $270 \mathrm{~m}$, (e) $320 \mathrm{~m}$, and (f) $370 \mathrm{~m}$.

becomes unnoticeable starting at the strata $40 \mathrm{~m}$ above No. 9 seam; therefore, the two-peak curves turn one-peak. It is also observed that, for the vertical displacement above Face $\mathrm{B}_{3}$, the slope rates of the curves at the left side are larger than the right side, corresponding to the more fractured separation zone observed on the left side of Face $B_{3}$ (see Figure 13).

The contours of the slope vertical displacement after completion of Faces $B_{2}$ and $B_{3}$ are shown in Figure 15 . The overall vertical displacement is around -0.5 to $-1 \mathrm{~m}$ at the cease of Face $B_{2}$ (Figure $15(\mathrm{a})$ ) and -1 to $-1.5 \mathrm{~m}$ for Face $\mathrm{B}_{3}$ (Figure 15(b)). The movement at the slope area is increased as the face approaches the slope [20].

3.3. Model III. In Model III, the only longwall face, Face $\mathrm{B}_{4}$, in the lower seam is mined. The development of strata movement with the face advance is shown in Figure 16. The overall intensity and extension of ground movement is mitigated as compared to the multiple-seam mining in Model I. Figure 16(a) plots the cave of the lower immediate roof extending $5 \mathrm{~m}$ above the seam; the cave of the immediate roof occurring at $140 \mathrm{~m}$ of face advance is shown in Figure 16(b), extending $12 \mathrm{~m}$ above the seam. When the face advances $75 \mathrm{~m}$ from the start position, the inverse arch-shaped roof structure and compaction of caved loose gob materials are observed (Figure 16(c)). Extension of disturbed overburden reaches $75 \mathrm{~m}$ above the seam, with a notable bed separation at the top of the disturbed configuration. The disturbed strata reach $105 \mathrm{~m}$ above the seam after $310 \mathrm{~m}$ of the face development (Figure 16(d)). The strata then extend to the ground surface at a further $60 \mathrm{~m}$ of face advance, where the bed separation is closed (Figure 16(e)). The dimension of the broken strata grows gradually with face development, but the general configurations look similar (Figures 16(f) and 16(g)). Face $\mathrm{B}_{4}$ ceases after $500 \mathrm{~m}$ of face advance.

Figure 17 identifies the caved zone, the fractured zone, and the bending zone in the vertical direction as well as the stable zone supported by the solid coal, the bed separation zone, and recompacted zone in the horizontal direction after the completion of Face $\mathrm{B}_{4}$. Since no pillar is maintained between panels, no superposition of the zones occurs. Therefore, the identified zones in the vertical and horizontal directions are more distinct and are similar to the typical zones shown in Figure 2. It also shows that the ground subsidence and cracks seem less distinct than Models I and II. The angle of break is about $30^{\circ}$, which is similar to previous models. 


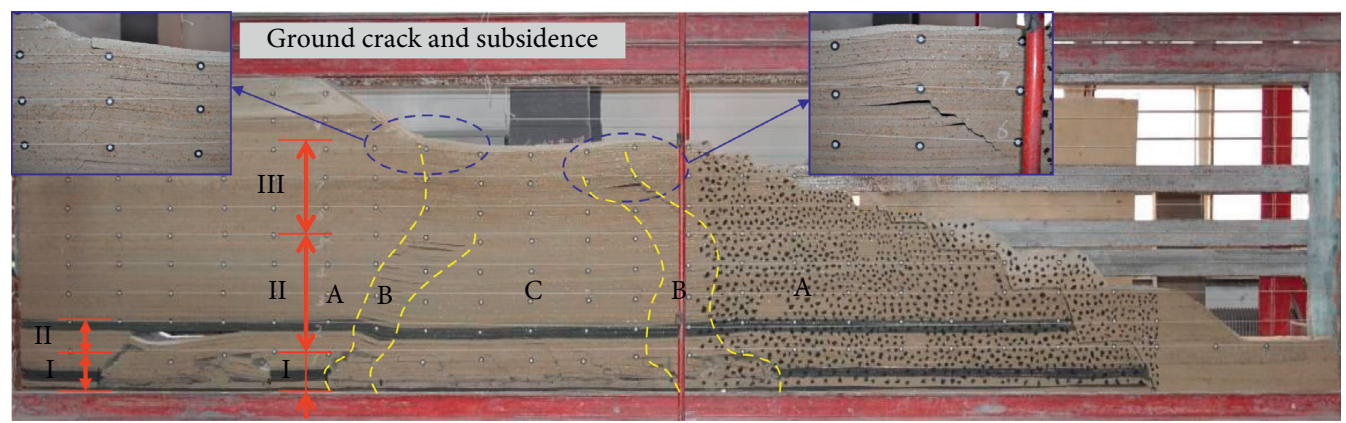

Figure 13: Final view of the ground movement at completion of Faces $\mathrm{B}_{2}$ and $\mathrm{B}_{3}$. I: caved zone; II: fractured zone; and III: continuous bending zone. (A) stable zone; (B) separation zone; and (C) recompacted zone.

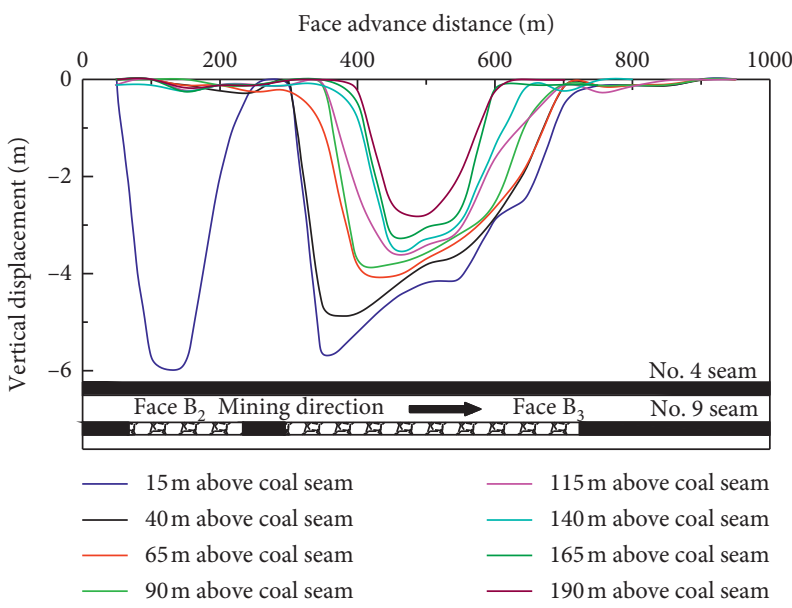

FIGURE 14: Strata vertical displacement after completion of Faces $\mathrm{B}_{2}$ and $\mathrm{B}_{3}$.

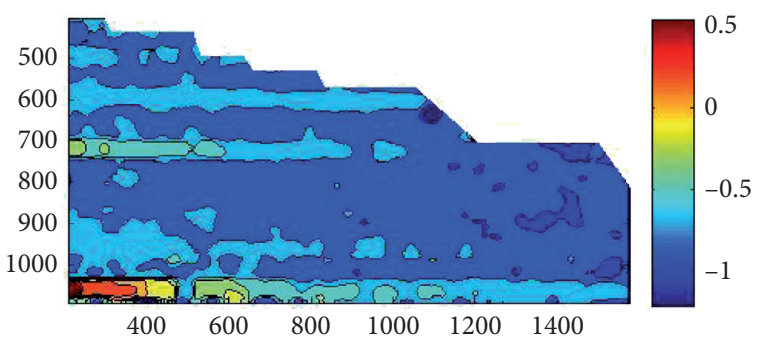

(a)

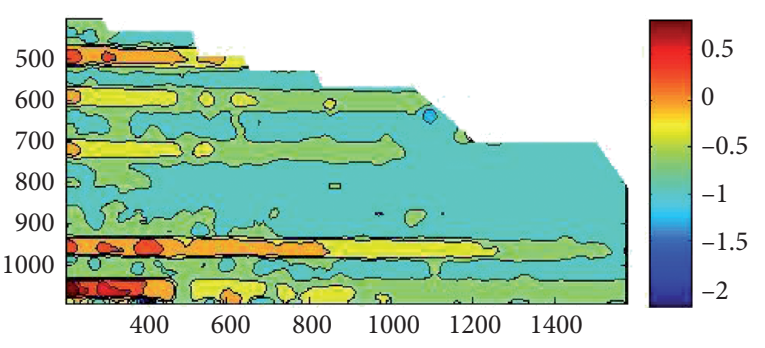

(b)

FIGURE 15: Slope vertical displacement contour after completion of (a) Faces $B_{2}$ and (b) $B_{3}$.

The vertical displacement of the strata at different distance above No. 9 seam is shown in Figure 18. The strata displacement starts to increase at the junction between the stable zone and separation zone. It reaches the maximum in the recompacted zone. Generally, the overburden strata closer to No. 9 seam show a larger displacement. At $15 \mathrm{~m}$ above the seam, the largest vertical displacement is about $3.8 \mathrm{~m}$, compared with only $2 \mathrm{~m}$ of vertical displacement at $165 \mathrm{~m}$ above the seam.

The comparison of roof vertical displacement for different models is given in Table 3. Due to the bed separation in the caved and fractured zones, it is more proper to compare the displacement at $165 \mathrm{~m}$ above the seam, which represents the ground movement in the continuous bending zone. Model I shows the largest strata displacement mainly due to the intensive multiseam mining activity, followed by Models II and III in the descending order. The shallower depth of cover for Model II might be responsible for the relative larger displacement than Model III.

The slope vertical displacement field after completion of Face $B_{4}$ is shown in Figure 19. The overall vertical displacement is around 0 to $-2 \mathrm{~m}$. As compared to Models I and 


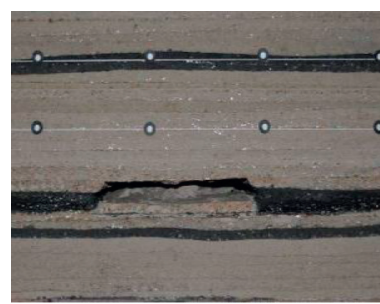

(a)

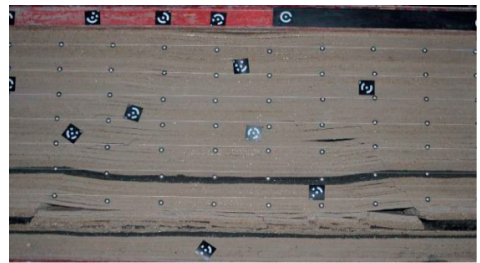

(e)

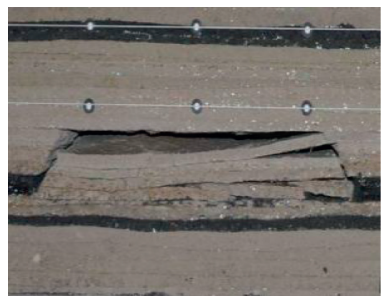

(b)

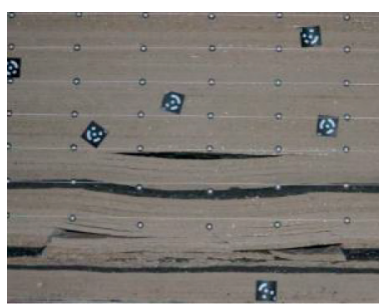

(c)

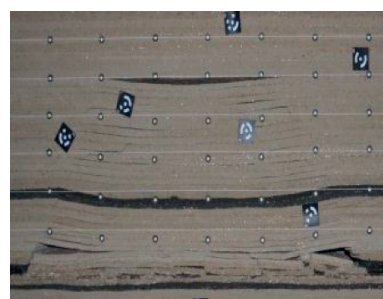

(d)

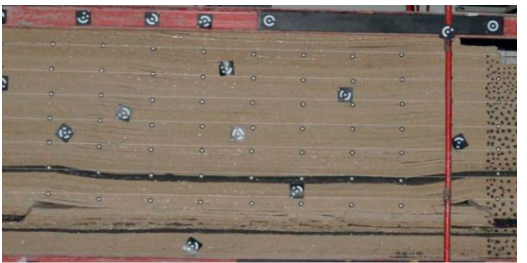

(f)

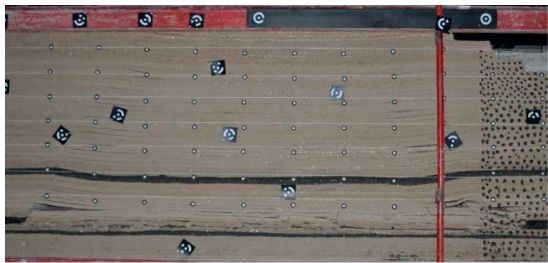

(g)

Figure 16: Progressive development of strata movement with advance of Face $B_{4}$. Face advance distance: (a) $70 \mathrm{~m}$, (b) $140 \mathrm{~m}$, (c) $220 \mathrm{~m}$, (d) $310 \mathrm{~m}$, (e) $370 \mathrm{~m}$, (f) $470 \mathrm{~m}$, and (g) $500 \mathrm{~m}$.

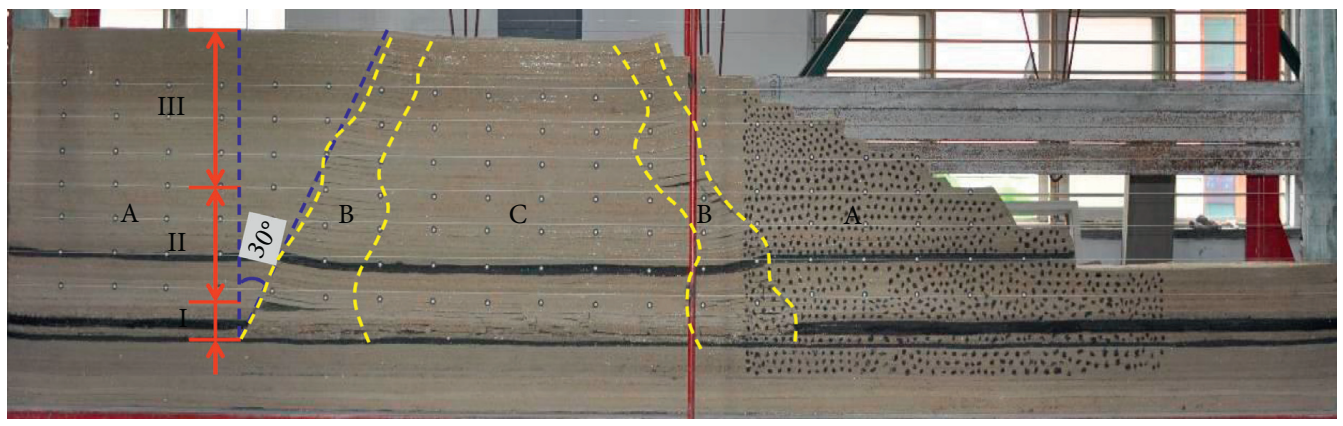

FIGURE 17: Final view of the ground movement at completion of Face $\mathrm{B}_{4}$. I: caved zone; II: fractured zone; and III: continuous bending zone. (A) stable zone; (B) separation zone; and (C) recompacted zone.

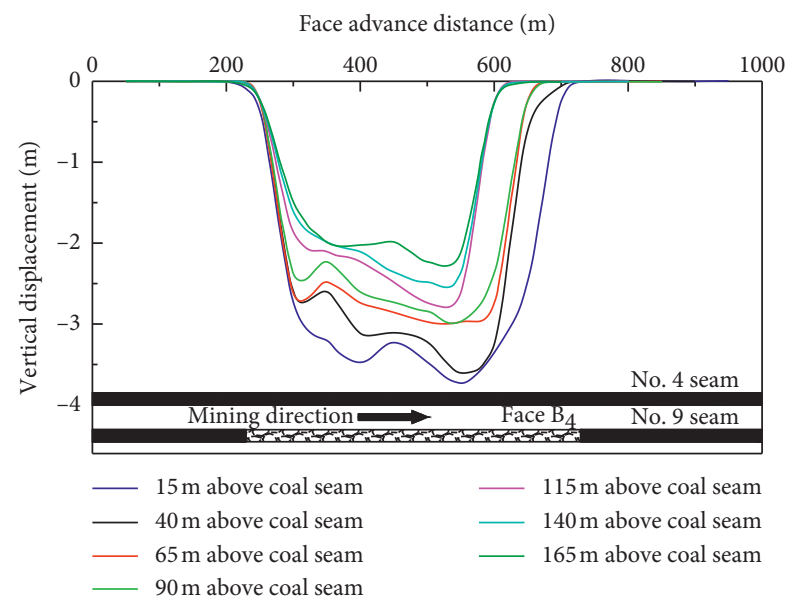

FIGURE 18: Strata vertical displacement after completion of Face $B_{4}$.

II, the slope movement is slightly mitigated. The ground movement at the slope area may depend on the intensity of mining activities and the mining positions relative to the
TABLe 3: Comparison of roof vertical displacement at $15 \mathrm{~m}$ and $165 \mathrm{~m}$ above No. 9 seam.

\begin{tabular}{lccc}
\hline $\begin{array}{l}\text { Strata vertical } \\
\text { displacement }\end{array}$ & $\begin{array}{c}\text { Model I } \\
(\mathrm{m})\end{array}$ & $\begin{array}{c}\text { Model II } \\
(\mathrm{m})\end{array}$ & $\begin{array}{c}\text { Model III } \\
(\mathrm{m})\end{array}$ \\
\hline $15 \mathrm{~m}$ above No.9 seam & 10 & 6 & 3.8 \\
$165 \mathrm{~m}$ above No.9 seam & 7 & 3.2 & 2 \\
\hline
\end{tabular}

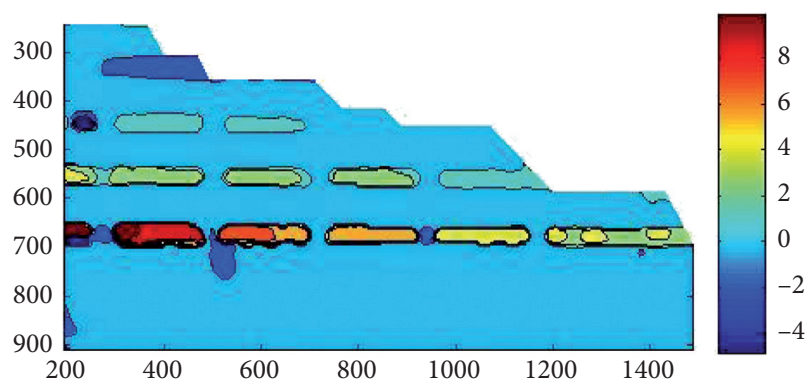

Figure 19: Slope vertical displacement contour after completion of Face $\mathrm{B}_{4}$. 
mine slope. The slope movement is increased with the increase of mining intensity and the approach of longwall face to the slope.

\section{Discussion and Conclusions}

With the development of the dimensions of the open pit, the coal mine starts to adopt the underground longwall mining method for recovering the coal seam to improve the production and profits. However, the ground movement and surface subsidence may also be increased due to the intensive and large-scale combined surface and underground mining activities. In this paper, the ground movement of the combined surface and underground mining of an open-pit mine is reproduced on a large-size physical modelling rig. Three physical models are developed to assess the roof failure characteristics, the strata movement process, strata vertical displacement, and the zone identification along the horizontal and vertical directions. The influence of the underground mining on the ground movement at the slope area is also included. Important findings of this study are listed below.

(1) Faces $A_{1}$ and $A_{2}$ in the upper seam and Face $B_{1}$ in the lower seam are included in Model I. Faces $A_{1}$ and $A_{2}$ are first mined, followed by the extraction of Face $B_{1}$. An inverse arch-shaped roof block structure is created upon the failure of the competent strong roof. The structure compacts the loose gob materials in the caved zone but leaves a bed separation at the top of the disturbed configuration. During the extraction of Face $B_{1}$, the caved and fractured zones for the lower seam extend and connect with the upper ones, leading to the massive collapse of the overburden strata. Massive ground cracks and shear movement on the slope step are created by the largescale multiseam mining activities. The maximum roof vertical displacement in the continuous bending zone reaches $6 \mathrm{~m}$.

(2) Faces $B_{1}$ and $B_{2}$ in the lower seam are mined in Model II. A $50 \mathrm{~m}$ coal pillar is maintained between the two faces. The ground movement is much mitigated as compared to Model I. The bed separation above the inverse arch-shaped structure extends upward with the face advance and is closed when it reaches the continuous bending zone. Only the caved and fractured zones are observed above Face $B_{1}$ due to the limited distance of face advance, while the continuous bending zone is found above Face $B_{2}$. The ground crack is also observed on the surface but is significantly smaller than the massive crack caused by the intensive multiseam mining. The vertical displacement of the strata in the continuous zone (at $165 \mathrm{~m}$ above No. 9 seam) is about $3.2 \mathrm{~m}$.

(3) Face $\mathrm{B}_{4}$ in the lower seam advances a total of $500 \mathrm{~m}$ in Model III. This face is the only longwall face in the model; therefore, the three zones in the vertical and horizontal directions are clearly identified and no superposition of the zones is observed. The angle of break after completion of the face is approximately $30^{\circ}$, similar to the rest of the faces. The strata in the continuous bending zone displace $2 \mathrm{~m}$ in the vertical direction.

(4) The ground movement in the slope area is mostly affected by the underground mining in Model I, followed by Models II and III in the descending order. The extent of slope movement increases with not only the intensity and scale of the mining activity, but also as the longwall face approaches the slope.

\section{Data Availability}

The data used to support the findings of this study are included within the article.

\section{Conflicts of Interest}

The authors declare that there are no conflicts of interest regarding the publication of this paper.

\section{Acknowledgments}

The financial support from the National Natural Science Foundation of China (51974320, 51904082, and 51774184), Beijing Natural Science Foundation (2204080), Science and Technology Plan of Beijing Municipal Education Commission (KM202010009001), and North China University of Technology (110051360002, 107051360019XN134/017, and $107051360019 X N 134 / 020)$ is greatly appreciated.

\section{References}

[1] J.-h. Chen, D.-s. Gu, and J.-x. Li, "Optimization principle of combined surface and underground mining and its applications," Journal of Central South University of Technology, vol. 10, no. 3, pp. 222-225, 2003.

[2] E. Bakhtavar, "The practicable combination of open pit with underground mining methods-a decade's experience," in Proceedings of the 24th International Mining Congress and Exhibition of Turkey (IMCET), Antalya, Turkey, April 2015.

[3] E. Bakhtavar, J. Abdollahisharif, and A. Aminzadeh, "A stochastic mathematical model for determination of transition time in the non-simultaneous case of surface and underground mining," The Journal of the Southern African Institute of Mining and Metallurgy, vol. 117, no. 12, pp. 1145-1153, 2017.

[4] E. Bakhtavar, "Transition from open-pit to underground in the case of Chah-Gaz iron ore combined mining," Journal of Mining Science, vol. 49, no. 6, pp. 955-966, 2013.

[5] E. Bakhtavar, "A study on geotechnical risks in the interaction between open-pit and block caving," in Proceedings of the 30th International Conference on Ground Control in Mining, Morgantown, WV, USA, July 2011.

[6] E. Bakhtavar, K. Oraee, and K. Shahriar, "Determination of crown pillar thickness between open-pit and block cave mining," in Proceedings of the 29th International Conference on Ground Control in Mining, Morgantown, WV, USA, July 2010.

[7] Z. W. Wang, J. G. Wang, and Y. J. Yu, "Deformation evolution regulation of loess floor earth-disposal site affected by open- 
pit and underground mining," Journal of Liaoning Technical University (Natural Science), vol. 27, no. 2, pp. 165-167, 2008.

[8] G. Song, Z. Wang, and K. Ding, "Evaluation of the face advance rate on ground control in the open face area associated with mining operations in Western China," Journal of Geophysics and Engineering, vol. 17, no. 2, pp. 390-398, 2020.

[9] G. Song and S. Yang, "Investigation into strata behaviour and fractured zone height in a high-seam longwall coal mine," Journal of the Southern African Institute of Mining and Metallurgy, vol. 115, no. 8, pp. 781-788, 2015.

[10] G. Song, K. Ding, and D. Kong, "Assessing longwall shieldstrata interaction using a physical model," Quarterly Journal of Engineering Geology and Hydrogeology, vol. 52, no. 4, pp. 536-546, 2019.

[11] G. F. Song, S. L. Yang, and Z. H. Wang, "Longwall face stability analysis using Ritz method and its 3D physical modelling study," Journal of China Coal Society, vol. 43, no. 8, pp. 2162-2172, 2018.

[12] S. Yang, G. Song, and D. Kong, "An evaluation of longwall face stability in thick coal seams through a basic understanding of shield-strata interaction," Journal of Geophysics and Engineering, vol. 16, no. 1, pp. 125-135, 2019.

[13] S. L. Yang, J. C. Wang, and J. H. Yang, "Physical analog simulation analysis and its mechanical explanation on dynamic load impact," Journal of China Coal Society, vol. 42, no. 2, pp. 335-343, 2017.

[14] S. G. Sun, M. F. Cai, and S. J. Wang, "Study of sliding mechanism for slope due to the excavation from open pit into underground mining," Chinese Journal of Rock Mechanics and Engineering, vol. 19, no. 1, pp. 126-129, 2000.

[15] J. M. Zhu, X. Q. Liu, J. Y. Feng et al., "Study on slope stability and optimization of boundary parameters under condition of combined open-underground mining," Chinese Journal of Rock Mechanics and Engineering, vol. 28, no. s2, pp. 39713977, 2009.

[16] J. M. Zhu, J. Y. Feng, X. P. Peng et al., "The failure law of mine slope and the optimization of boundary parameter between open-pit and underground combined mining," Journal of China Coal Society, vol. 35, no. 7, pp. 1089-1094, 2010.

[17] X. Q. Liu, J. M. Zhu, J. Y. Feng et al., "Mechanism of the slope failure of horizontal thick coal seam under the condition of combined mining," Journal of China Coal Society, vol. 33, no. 12, pp. 1346-1350, 2008.

[18] M. G. Qian and P. W. Shi, Coal Mine Pressure and Strata Control, China University of Mining and Technology Press, Xuzhou, China, 2003.

[19] V. Palchik, "Formation of fractured zones in overburden due to longwall mining," Environmental Geology, vol. 44, no. 1, pp. 28-38, 2003.

[20] P. S. Zhang, X. W. Wu, and S. D. Liu, "Study of dynamic detection simulation of overburden failure in model workface," Chinese Journal of Rock Mechanics \& Engineering, vol. 30, no. 1, pp. 78-83, 2011.

[21] Q. X. Sun, Y. Mou, and X. L. Yang, "Study on two-zone height of overlying of fully-mechanized technology with high mining height at Hongliu coal mine," Journal of China Coal Society, vol. 38, no. s2, pp. 283-286, 2013.

[22] V. Palchik, "Use of Gaussian distribution for estimation of gob gas drainage well productivity," Mathematical Geology, vol. 34, no. 6, pp. 743-765, 2002.

[23] H. Kratzsch, Mining Subsidence Engineering, Springer, Berlin, Germnay, 2012.

[24] V. Palchik, "Localization of mining-induced horizontal fractures along rock layer interfaces in overburden: field measurements and prediction," Environmental Geology, vol. 48 , no. 1 , pp. $68-80,2005$.

[25] V. Palchik, "Influence of physical characteristics of weak rock mass on height of caved zone over abandoned subsurface coal mines," Environmental Geology, vol. 42, no. 1, pp. 92-101, 2002.

[26] T. B. Zhao, C. L. Liu, and Z. Y. Xiao, "Numerical simulation on the distribution evolution of overburden fractured zone in coal mining and its visual detection," Applied Mechanics and Materials, vol. 170-173, pp. 842-846, 2012.

[27] W. Ren, C. Guo, Z. Peng, and Y. Wang, "Model experimental research on deformation and subsidence characteristics of ground and wall rock due to mining under thick overlying terrane," International Journal of Rock Mechanics and Mining Sciences, vol. 47, no. 4, pp. 614-624, 2010.

[28] J. Ju and J. Xu, "Surface stepped subsidence related to top-coal caving longwall mining of extremely thick coal seam under shallow cover," International Journal of Rock Mechanics and Mining Sciences, vol. 78, pp. 27-35, 2015.

[29] V. Palchik, "Experimental investigation of apertures of mining-induced horizontal fractures," International Journal of Rock Mechanics and Mining Sciences, vol. 47, no. 3, pp. 502-508, 2010.

[30] V. Palchik, "Bulking factors and extents of caved zones in weathered overburden of shallow abandoned underground workings," International Journal of Rock Mechanics and Mining Sciences, vol. 79, pp. 227-240, 2015.

[31] G. Cheng, T. Ma, C. Tang, H. Liu, and S. Wang, “A zoning model for coal mining_induced strata movement based on microseismic monitoring," International Journal of Rock Mechanics and Mining Sciences, vol. 94, pp. 123-138, 2017. 